\title{
SYNTHETIC LH-RELEASING FACTOR AND CLOMIPHENE STIMULATION IN OLIGOSPERMIC MALES WITH NORMAL FSH EXCRETION
}

\author{
J. MAUSS,* G. MOHNFELD AND G. BÖRSCH \\ Department of Dermatology, University of Essen, D-4300 Essen, West Germany
}

(Received 2nd November 1973)

It now seems reasonably established that males with a severe impairment of testicular tubular function tend to have elevated FSH levels, while, contrary to previous concepts, gonadotrophin levels associated with the syndrome of hypogonadotrophic hypogonadism are not necessarily low but are frequently in the lower normal adult range (Franchimont, Burger \& Legros, 1973). This emphasizes the need for reliable diagnostic methods to differentiate patients with hypogonadotrophic hypogonadism from other sub- or infertile males. Tests of hypothalamic and pituitary function, utilizing clomiphene citrate and LH-releasing factor (LH-RF) respectively, have been successfully used (Santen, Leonard, Sherins, Gandy \& Paulsen, 1971; Marshall, Harsoulis, Anderson, McNeilly, Besser \& Hall, 1972). The performance of these stimulation tests involves the assay of FSH and LH, usually in serum or plasma, and their application has therefore been restricted to a few well-equipped endocrinological centres with radioimmunoassay techniques at their disposal.

The development of new immunochemical tests for the assay of FSH and LH by Schuurs \& van Wijngaarden (1974) has made possible a simple semiquantitative analysis of urinary gonadotrophins. In a large number of suband infertile males, these tests have yielded results which were in good agreement with current concepts of pituitary-gonadal interrelations (Mauss \& Börsch, 1973).

Elevated baseline FSH levels were found in $75 \%$ of oligospermic males, while the remainder had FSH levels in the normal range despite a low sperm output, suggesting the possibility of at least partial hypothalamic or pituitary insufficiency. In a further investigation of this possibility, the effects of stimulation with clomiphene citrate and LH-RF have been studied in sub- or infertile males, aged 25 to 39 years, with oligospermia $\left(<5 \times 10^{6}\right.$ spermatozoa $\left./ \mathrm{mI}\right)$ and a basal FSH excretion in the normal range. Ten healthy medical students, aged 24 to 30 years and with testes of normal volume $(>12 \mathrm{ml})$ as measured by an orchidometer (Schonfeld, 1943) and normal sperm characteristics as defined by Mauss \& Börsch (1973), served as controls.

Immediately before the clomiphene test, two 24-hr urine samples were collected on consecutive days. The subjects then received 50-mg doses orally

* Present address: Department of Dermatology, Evangelisches Krankenhaus, P.O. Box 2940, D-4000 Düsseldorf 1, West Germany. 

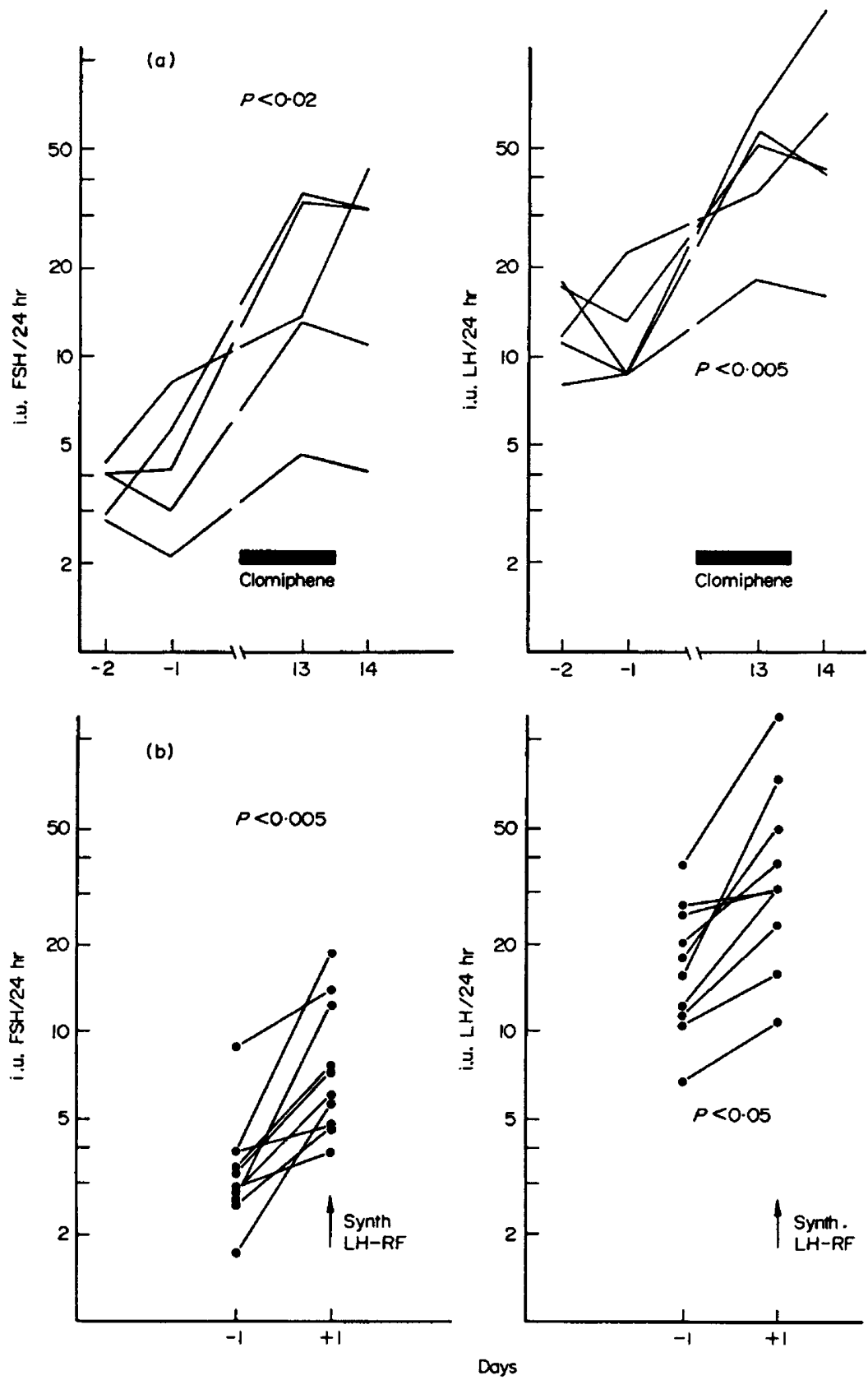

TExT-PIG. 1. Effects of (a) clomiphene citrate and (b) synthetic LH-RF on urinary FSH and LH excretion by normal males. Results were obtained using an immunoassay and are plotted in a semilogarithmic fashion. The baseline gonadotrophin levels are marked Day -1 and Day -2 , and the significance values for the increased levels of gonadotrophins after stimulation are shown. 
of clomiphene citrate (Dyneric: Merrell Pharma, Gross-Gerau) four times a day for 13 days and two more 24-hr urine samples were collected on Days 13 and 14 .

For the LH-RF test, 24-hr urine samples were collected on 2 consecutive days. On the 2nd day, all subjects received a total of seven subcutaneous injections of $100 \mu \mathrm{g}$ synthetic LH-RF (Farbwerke Hoechst, Frankfurt), starting at 07.00 hours, with a time interval of $2 \frac{1}{2} \mathrm{hr}$ between injections.

Clomiphene tests and LH-RF tests were performed on five and ten normal males respectively, and on nine and five oligospermic males, respectively. When clomiphene stimulation was carried out before the LH-RF tests, at least 2 weeks were allowed to elapse between the tests. Urine samples were assayed for FSH and $\mathrm{LH}$ using immunochemical haemagglutination inhibition reactions (Schuurs \& van Wijngaarden, 1974) as described previously (Mauss \& Börsch, 1973).

The results of the clomiphene and LH-RF tests in normal males are shown in Text-figs 1 (a) and 1(b). In the clomiphene tests, the mean FSH and LH excretion increased from 3.9 i.u. to 15.4 i.u. and from 12.2 i.u. to 41.9 i.u., respectively. In the LH-RF tests, the respective mean values were 3.3 i.u. to 7.4 i.u. and 15.7 i.u. to 33.7 i.u. As judged by Student's $t$ test, the mean FSH and LH excretion after stimulation was significantly higher than the gonadotrophin excretion in the basal state in both tests $(P<0.05)$.

The results of stimulation tests in oligospermic patients were very similar (Text-figs $2 \mathrm{a}$ and $2 \mathrm{~b}$ ). The mean pre- and post-treatment levels were 3.8 and 9.7 i.u. for FSH and 11.0 and 46.5 i.u. for $\mathrm{LH}$ in the clomiphene tests, and 4.6 and 13.0 i.u. for FSH and 12.1 and 52.9 i.u. for LH in the LH-RF tests. The post-treatment levels were significantly higher $(P<0.01)$ in both tests. There were no significant differences when the mean gonadotrophin levels of patients before and after stimulation in both tests were compared with the corresponding levels for normal males. A marked variability of individual response to stimulation was observed in both tests.

The treatment with synthetic LH-RF over a period of $15 \mathrm{hr}$ resulted in an augmented gonadotrophin release large enough to cause a substantial rise of gonadotrophin excretion in the 24-hr urine samples collected on the day of stimulation. This increase could not be accounted for by daily fluctuations of urinary gonadotrophin excretion (Börsch \& Mauss, 1973). The increase of FSH excretion was very similar to the increase of LH excretion but, after single injections of LH-RF, serum FSH levels have been shown to rise distinctly less than serum LH levels (Marshall et al., 1972). A tempting explanation for this phenomenon would be the longer half-life of FSH (Coble, Kohler, Cargille \& Ross, 1969) compared to that of LH (Kohler, Ross \& Odell, 1968), resulting in a more sustained elevation of plasma FSH levels and possibly causing an increased renal excretion.

No adverse effects were observed in any of the subjects receiving LH-RF. By contrast, visual disturbances and increased aggression were reported by all the normal subjects and seven out of nine oligospermic males taking clomiphene citrate. Similar side-effects have also been described by Anderson, Marshall, Young \& Fraser (1972). 

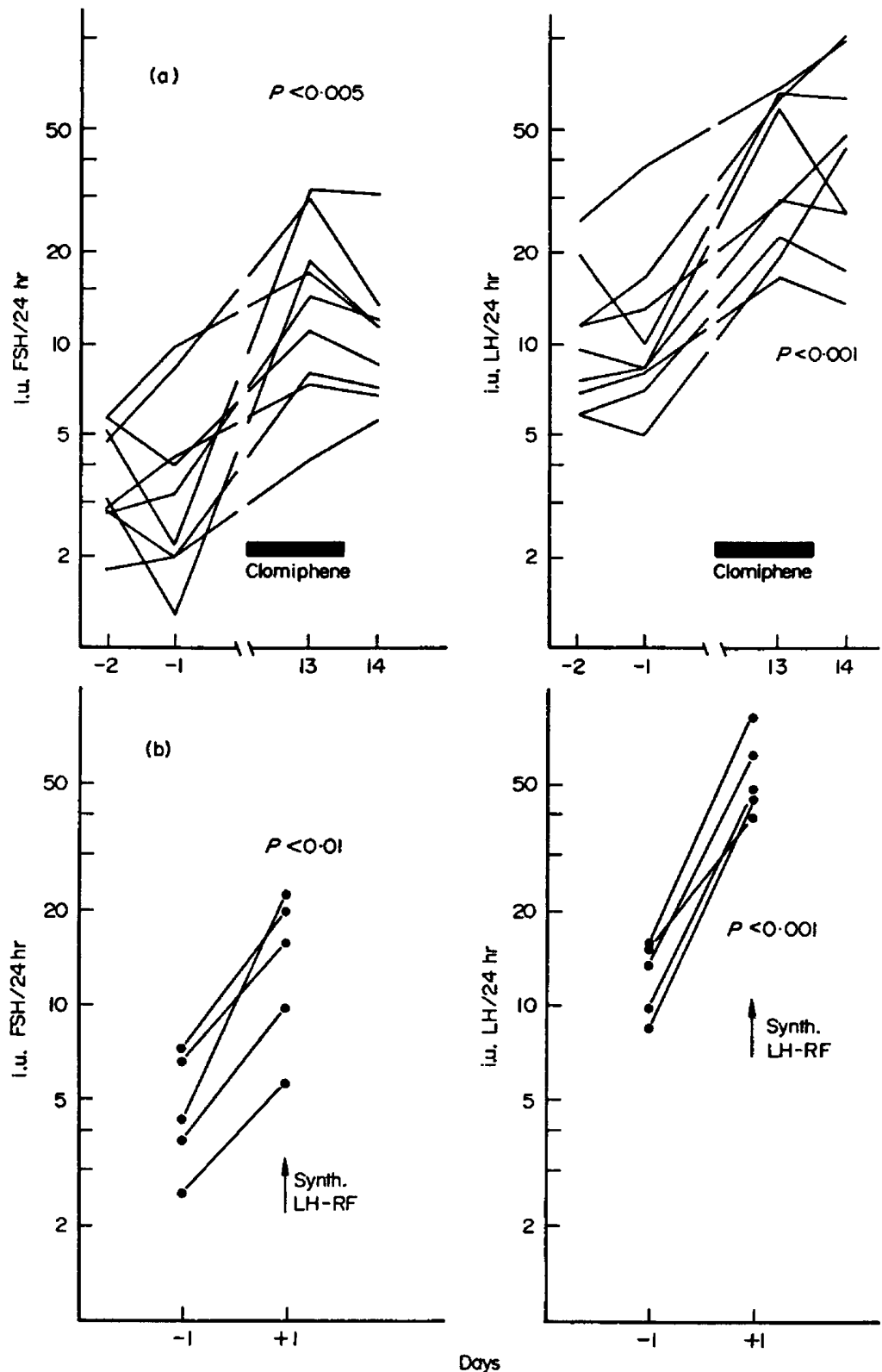

TexT-FIG. 2. Effects of (a) clomiphene citrate and (b) synthetic LH-RF on urinary FSH and LH excretion by oligospermic males with normal basal FSH levels. Results were obtained using an immunoassay and are plotted in a semilogarithmic fashion. The baseline gonadotrophin levels are marked Day -1 and Day -2 , and the significance values for the increased levels of gonadotrophins after stimulation are shown. 
In this study, no difference was found in the gonadotrophic response to clomiphene and LH-RF stimulation between normal males and highly oligospermic patients with normal basal FSH levels. If an adequate response to clomiphene and LH-RF stimulation is accepted as proof of the integrity of the hypothalamus-pituitary-gonadal axis, then the oligospermia found in our patients cannot be attributed to pituitary insufficiency. A possible cause for the low sperm output may be a partial or complete block to the egress of spermatozoa (Rowley \& Heller, 1972), leaving spermatogenesis undisturbed. The patients studied here would thus be unlikely to benefit from any hormonal replacement therapy.

The authors wish to acknowledge gifts of synthetic LH-RF by Farbwerke Hoechst AG, Frankfurt, Germany, and of FSH-Nosticon and Luteonosticon tests by Organon Scientific Development Group, Oss, The Netherlands.

\section{REFERENCES}

Anderson, D. G., Marshall, J. G., Young, J. L. \& Fraser, T. R. (1972) Stimulation tests of pituitaryLeydig cell function in normal male subjects and hypogonadal men. Clin. Endocr. 1, 127.

Börsch, G. \& Mauss, J. (1973) Konstanz der immunochemisch bestimmten FSH/LH-Ausscheidung beim Mann. Andrologie, 5, 347.

Coble, Y. D., JR, Kohler, P. O., CArgille, C. M. \& Ross, G. T. (1969) Production rates and metabolic clearance rates of human follicle-stimulating hormone in premenopausal and postmenopausal women. $\mathcal{F}$. clin. Invest. 48, 359.

Franchimont, P., Burger, H. \& Legros, J. J. (1973) Impact of radioassay techniques on the field of sex hormones. Metabolism, 22, 1003.

Kohler, P. O., Ross, G. T. \& Odell, W. D. (1968) Metabolic clearance and production rates of human luteinizing hormone in pre- and postmenopausal women. . clin. Invest. 47, 38.

Marshall, J. G., Harsoulis, P., Anderson, D. C., MaNeilly, A. S., Besser, G. M. \& Hall, R. (1972) Isolated pituitary gonadotrophin deficiency: gonadotrophin secretion after synthetic luteinizing hormone and follicle stimulating hormone-releasing hormone. Br. med. F. iv, 643.

MAuss, J. \& BöRsCH, G. (1973) Immunochemical assay of follicle-stimulating and luteinizing hormone in the unconcentrated urine of sub- or infertile males. Acta endocr., Copenh. 74, 631.

Rowley, M. J. \& Heller, G. G. (1972) The testosterone rebound phenomenon in the treatment of male infertility. Fert. Steril. 23, 498.

Santen, R. J., Leonard, J. M., Sherins, R. J., Gandy, H. M. \& Paulsen, G. A. (1971) Short- and long-term effects of clomiphene citrate on the pituitary-testicular axis. F. clin. Endocr. 33, 970.

Schonfeld, W. A. (1943) Primary and secondary sexual characteristics. Study of their development in males from birth through maturity, with biometric study of penis and testes. Am. F. Dis. Child. 65, 535.

Schuurs, A. H. W. M. \& van WijngaArden, C. J. (1974) A modified haemagglutination inhibition test for estimating follicle stimulating hormone (FSH) in unprocessed urine. F. Obstet. Gynaec. $B r$. Commonw. (In press). 